\title{
Discussion of paper by A. Shabbir, Q. Huang, G. Baeza, D. Vlassopoulos, Q. Chen, R. H. Colby, N. J. Alvarez and O. Hassager, entitled 'Nonlinear shear and uniaxial extensional rheology of polyether-ester-sulfonate copolymer ionomer melts'
}

Shabbir, A.; Huang, Q.; Baeza, G.; Vlassopoulos, D.; Chen, Q.; Colby, R. H.; Alvarez, N. J.; Hassager, Ole; Wang, Zuowei; Creton, Constantino

Total number of authors:

13

Published in:

Journal of Rheology

Link to article, DOI:

10.1122/1.5008879

Publication date:

2017

Document Version

Peer reviewed version

Link back to DTU Orbit

Citation (APA):

Shabbir, A., Huang, Q., Baeza, G., Vlassopoulos, D., Chen, Q., Colby, R. H., Alvarez, N. J., Hassager, O., Wang, Z., Creton, C., van Ruymbeke, E., Coppola, S., \& Ramirez, J. (2017). Discussion of paper by A. Shabbir, Q. Huang, G. Baeza, D. Vlassopoulos, Q. Chen, R. H. Colby, N. J. Alvarez and O. Hassager, entitled 'Nonlinear shear and uniaxial extensional rheology of polyether-ester-sulfonate copolymer ionomer melts'. Journal of Rheology, 61(6), 1291-1291. https://doi.org/10.1122/1.5008879

\section{General rights}

Copyright and moral rights for the publications made accessible in the public portal are retained by the authors and/or other copyright owners and it is a condition of accessing publications that users recognise and abide by the legal requirements associated with these rights.

- Users may download and print one copy of any publication from the public portal for the purpose of private study or research.

- You may not further distribute the material or use it for any profit-making activity or commercial gain

- You may freely distribute the URL identifying the publication in the public portal 


\section{Questions JOR - Paper presented by A. Shabbir}

Discussion of paper by A. Shabbir, Q. Huang, G. Baeza, D. Vlassopoulos, Q. Chen, R. H. Colby,

N. J. Alvarez and O. Hassager, entitled 'Nonlinear shear and uniaxial extensional rheology of

polyether-ester-sulfonate copolymer ionomer melts'

By: Shabbir, A.; Huang, Q.; Baeza, G.; et al.

JOURNAL OF RHEOLOGY Volume: 61 Issue: 6 Special Issue: SI Pages: 1291-1291

\section{Zuowei Wang:}

How many charges are there per chain? What is the average cluster size?

Answer: Seven charges per chain. The average cluster size is a few nanometers.

\section{Constantino Creton:}

You said that ionomers break at stresses of the order of the plateau modulus, but acrylic acid based materials break at much higher stresses.

Answer: It depends also on the strength or the activation energy of the sticker. If the physical crosslink or bond is a strong one then diffusional mechanisms leading to dissipation in the system are somewhat restricted and the only way for the system to accommodate the stress would be to break at low stress for this specific case the stress is of the order of plateau modulus. But acrylic based systems do break at much higher stresses because the bonds are weak allowing for dissipative mechanisms to accommodate higher stresses during stretching.

Maybe weak is better than strong in this case?

Answer: indeed.

Evelyne van Ruymbeke:

Does association time decrease in the stretch state? How do you take into account this possible decrease of the association times? Does it affect your analysis based on Wi number?

Answer: That is a good question. Sticker life time is a notion used for equilibrium dynamics. I think that the stretched bonds break more quickly than the non-stretched ones. In the current analysis, this has not been considered. It would certainly be worth looking at for understanding the fracture mechanics of these systems.

\section{Salvatore Coppola:}

Did you try to adjust the waiting time prior to shear? A longer time might improve adhesion of polymer to the metal surface of the tools. This can help, also to avoid wall slip.

Answer: Annealing time of 1 hour at 120C was used for equilibration and to get a good contact with the plates before shearing.

\section{Jorge Ramirez:}


Regarding slide 19 on wall slip (Figure 4 in the paper), on the left panel the smallest shear rates are higher than those on the right! Did you try smaller extensional rates on the sample with $\beta=5 \%$ ?

Answer: Avoiding wall slip for such brittle samples is not easy. However, it could be very interesting to try and see if it persists also at low shear rates.

\section{Evelyne van Ruymbeke:}

You said that at low $\mathrm{T}$ you did not see strain hardening, but if you decrease the extension rate would you see it?

Answer: Probably, yes. Everything is relative. If rates are lower than the reciprocal of Wi number based on sticker life time one should see strain hardening. Alternatively, if you match the effective Weissenberg number of the higher T experiments at higher rates one should see strain hardening too as shown in the paper.

\section{Jorge Ramirez:}

For the fracture / breaking during extension, does the fracture always start at the surface, or sometimes at internal defects?

Answer: yes, it looks like it always breaks from the edge, but it could be surface defects such as bubbles. This fracture is distinct from necking. Fracture in our experiments always initiates from the edge.

\section{Hadi Goldansaz (from website):}

Q1) The master curve illustrated in Fig7.b is very interesting, though I was wondering if there is any significant difference between the extensional data of the current ionomers and equivalent comb polymers?

Q2) Sticker life time has a broad window in many supramolecular polymers due to different possible modes or hierarchy of associations. I was wondering if authors can comment on the viscoelastic behavior of a similar system with a broad sticker life time; for instance similar system replacing sulfonated groups with terpyridine ligands that can form binary complexes as well as pi-pi stacking arrangements 
